\title{
Assessment of Greenhouse Gas Emissions in Winter Wheat Farms Using Data Envelopment Analysis Approach
}

\author{
Alina Syp ${ }^{1 *}$, Antoni Faber ${ }^{1}$, Magdalena Borzęcka-Walker ${ }^{1}$, Dariusz Osuch ${ }^{2}$ \\ 'Institute of Soil Science and Plant Cultivation - State Research Institute, \\ Department of Agrometorology and Applied Informatics, Czartoryskich 8, 24-100 Puławy, Poland \\ ${ }^{2}$ Institute of Agricultural and Food Economics - National Research Institute, \\ Agricultural Accountancy Department, Świętokrzyska 20, 00-002 Warsaw, Poland
}

Received: April 14, 2015

Accepted: June 10, 2015

\begin{abstract}
Data envelopment analysis (DEA) has been recognized as a suitable tool for efficiency assessment of the economic and environmental performance of multiple similar units in the agri-food sector. In the present study, DEA methodologies were applied to 55 winter wheat farms in three farm sizes in Poland to benchmark the level of operational efficiency for each producer. Next, the potential reduction in the consumption levels of inputs were defined, and the environmental profits linked to these reduction targets were calculating. Our results indicate that $55 \%$ of the analysed farms operated efficiently. The technical efficiency scores of inefficient farms were 0.72 for small farms and 0.84 for medium and large ones. The production of $1 \mathrm{~kg}$ winter wheat results with average greenhouse gas (GHG) emissions of $0.448,0.481$, and $0.411 \mathrm{~kg} \mathrm{CO}_{2}$ eq. per $\mathrm{kg}$ of grain, for small, medium, and large farms, respectively. The performed analysis shows that GHG emissions per hectare depend on farm size and ranged from $2,378 \mathrm{~kg} \mathrm{CO}_{2}$ eq. for the small farms to $2,759 \mathrm{~kg} \mathrm{CO}_{2}$ eq. for large farms. The reduction of material input in inefficient farms, converted into environmental gains, resulted in GHG emissions reduction of 25.7, 29.0, and 28.6\% for small, medium, and large farms, respectively. The estimated potential reduction of global warming potential (GWP) according to the DEA for the whole sample ranged from 7 to $18 \%$, and was dependent on farm size. The major contributor to GWP was nitrous oxide field emissions (49-52\%), followed by nitrogen fertilizer (31-33\%), and diesel (11-13\%). Raising operational efficiency is recommended for potential environmental improvement in the surveyed region.
\end{abstract}

Keywords: environmental impact, global warming potential, nitrogen fertilizer, nitrous oxide field emissions, technical efficiency

\section{Introduction}

Wheat is cultivated under a wide range of environmental conditions. Its production is the third largest of cereals globally, after maize and rice [1]. In Poland, wheat is one of

*e-mail: asyp@iung.pulawy.pl the most important cereal crops, sown on 1.5 million ha, which represents $15 \%$ of the country's arable land [2]. Annual production amounts to 9.4 million tons, with an average yield of 4,140 kg per hectare in 2011 [2]. In general, in order to get higher productivity, farmers are using input resources in excess and inefficiently. Historically, the efficient use of inputs in agriculture did not have priority, 
but recently this has gained in importance. This is due to increasing population, limited availability of arable land, and the desire for higher living standards.

Agricultural practices contribute to greenhouse gas emissions (GHG) [3]. The FAO predicts that agricultural production will have increased $60 \%$ by 2050 , which will lead to a $30 \%$ increase in GHG emissions from the agricultural sector [4]. In Poland, the agriculture sector accounts for $10.7 \%$ of the country's GHG emissions. Currently, government institutions, farmers, and research communities are interested in a more sustainable agriculture that would implement technologies that have a positive effect on humans and the environment [5]. DEA is a non-parametric method used for the estimation of resource use efficiency, and ranking of production units on the basis of their performance $[6,7]$. This methodology has been used for the evaluation of environmental and economic farming performance [8-11].

The scope of our study was to analyse all the resources and processes that contribute to the production of one $\mathrm{kg}$ of wheat and associated GHG emissions. The production information used in our study was based on surveys conducted among producers.

The analysis was performed in order to:

1) show operationally inefficient wheat cultivation farms

2) quantify the environmental benefits of moving toward operational efficiency in winter wheat production, with the reduction of inputs decreasing potential environmental impacts.

The environmental output measurements were GHG emissions associated with each resource.

\section{Material and Methods}

\section{Site Description and Data Collection}

The study was carried out in the Wielkopolska and Silesian regions in south-central Poland. In this region, the cereal sowing area accounts for about $33 \%$ of the country's cereal sowing area. An average agricultural holding size in the analysed region is 16.4 ha, whereas in Poland it is 10.5 ha. The data used in the study was collected from 55 wheat farms using face-to-face questionnaires in 2010. The sample farms comes from the Farm Accountancy Data Network (FADN). The selected farms were divided into three groups based on wheat cultivation area. The first group includes farms where wheat is cultivated on an area lower or equal to 10 ha. This group consists of 19 farms, which were marked with the letter A. The second group also includes 19 farms ranging from 11 to 20 ha, and is indicated with the letter $\mathrm{B}$. The third group contains agricultural holdings whose surface is higher than 20 ha and lower or equal to 50 ha. This group includes 17 farms, and is marked with $\mathrm{C}$. The collected data were related to various inputs (diesel, machinery, seeds, chemical fertilizers, pesticides), soil quality, crop cultivation practices, crop rotation, and output (wheat yield). Crop rotation included winter wheat, rape, maize, and triticale. In order to evaluate the effect of farm size on GHG emissions and calculate the best wheat farm size, the farms were classified into three levels of wheat cultivation: (small $\leq 10 \mathrm{ha}$ ), medium (between 11 and $20 \mathrm{ha}$ ), and large (between 21 and $50 \mathrm{ha}$ ). To find out the calculated values for the three groups of farms - which are significantly different - all data were checked for normal distribution by the Shapiro-Wilk test. When the variables were normally distributed within each group, ANOVA test was applied at 95\% confidence.

\section{Data Envelopment Analysis}

The DEA model has been described in detail by several authors [6]. Production units are called decision-making units (DMUs) in DEA terminology [7]. In this study, the DMU was a farm that produces winter wheat (1 farm= 1 DMU) with the same inputs in the production process. For the assessment of a unit, an input-oriented efficiency model with constant return to scale (CRS) was selected. Input-oriented models are applied in agriculture because there is only one output, but numerous inputs. Furthermore, in the production system, a farmer has more control over input rather than output levels [12]. Some researchers state that GHG productions rely on finite and scarce resources, therefore the application of an input-oriented DEA models is more appropriate for reducing input consumption rates in production systems $[10,13]$. Different variables could be used to establish the farms' efficiency. In our analysis, wheat productivity is based on the following resources: chemical fertilizers $\left(\mathrm{kg} \cdot \mathrm{ha}^{-1}\right)$, pesticides $\left(\mathrm{kg} \cdot \mathrm{ha}^{-1}\right.$ of active ingredient), diesel $\left(1 \cdot \mathrm{ha}^{-1}\right)$, seeds $\left(\mathrm{kg} \cdot \mathrm{ha}^{-1}\right)$, and output, which is expressed as wheat yield $\left(\mathrm{kg} \cdot \mathrm{ha}^{-1}\right)$.

In order to calculate inputs and outputs, the collected data were entered into an Excel 2010 spreadsheet. To perform a DEA model DEAFrontier Software was used. All the selected operational items for DEA, implantation was assumed to be independent from each other.

\section{Calculation of GHG Emissions}

Operational and environmental patterns in wheat cultivation were evaluated based on five steps. The first step (I) includes data collection from wheat farms, the second step (II) is calculation of GHG of each farm, and the third (III) involves DEA study for the farms. The operational efficiency of each DMU is calculated along with the projection of inefficient DMUs (target values). Target DMUs refers to virtual units that consume less input and produce more outputs. In the fourth step (IV), calculation of GHG emissions of the target DMU is performed. The last step (V) involves the interpretation of the results. The potential environmental impacts for the virtual DMUs are compared with the current ones. The differences present quantitative measurements of the environmental impact of operational inefficiency in wheat cultivation. 
Table 1. Basic statistics descriptive of inputs and outputs for winter wheat production based on farm size.

\begin{tabular}{|c|c|c|c|}
\hline \multirow[b]{2}{*}{ Item (unit) } & \multicolumn{3}{|c|}{ Farm size groups (ha) } \\
\hline & $\begin{array}{l}\text { Small } \\
(<10)\end{array}$ & $\begin{array}{l}\text { Medium } \\
(11-20)\end{array}$ & $\begin{array}{l}\text { Large } \\
(21-50)\end{array}$ \\
\hline Average farm size (ha) & $8.2(1.9)^{\mathrm{a}}$ & $15.2(2.7)^{\mathrm{b}}$ & $29.3(8.0)^{\mathrm{c}}$ \\
\hline \multicolumn{4}{|c|}{ A. Inputs } \\
\hline Seeds $(\mathrm{kg})$ & $198(31)^{\mathrm{a}}$ & $219(90)^{\mathrm{a}}$ & $188(30)^{\mathrm{a}}$ \\
\hline $\mathrm{N}$ fertilizer (kg) & $126(51)^{\mathrm{a}}$ & $150.2(60)^{\mathrm{a}}$ & $150.8(43)^{\mathrm{a}}$ \\
\hline $\mathrm{P}_{2} \mathrm{O}_{5}$ fertilizer $(\mathrm{kg})$ & $45.4(25.1)^{\mathrm{a}}$ & $48.2(22.8)^{\mathrm{a}}$ & $46.7(22.9)^{\mathrm{a}}$ \\
\hline $\mathrm{K}_{2} \mathrm{O}$ fertilizer $(\mathrm{kg})$ & $53.3(33.2)^{\mathrm{a}}$ & $53.3(38.1)^{\mathrm{a}}$ & $45.3(40.5)^{\mathrm{a}}$ \\
\hline Pesticides (kg ) & $1.8(0.6)^{\mathrm{a}}$ & $1.6(1.1)^{\mathrm{a}}$ & $1.8(0.9)^{\mathrm{a}}$ \\
\hline Diesel (1) & $98(10.9)^{\mathrm{a}}$ & $91(10.4)^{\mathrm{a}}$ & $95(6.1)^{\mathrm{a}}$ \\
\hline Labour (h) & $8.5(1.5)^{\mathrm{a}}$ & $9.2(1.7)^{\mathrm{a}}$ & $8.5(1.5)^{\mathrm{a}}$ \\
\hline \multicolumn{4}{|c|}{ B. Output } \\
\hline Yield (kg) & $\begin{array}{c}5,309 \\
(1,187)^{\mathrm{a}}\end{array}$ & $\begin{array}{c}5,508 \\
(1,458)^{\mathrm{b}}\end{array}$ & $\begin{array}{c}6,718 \\
(1,042)^{\mathrm{c}}\end{array}$ \\
\hline
\end{tabular}

Values with different letters show significant difference of average at $5 \%$ (Scheffe test)

Numbers in parentheses indicate standard deviation

The GHG emissions in this study include emissions of nitrous oxide $\left(\mathrm{N}_{2} \mathrm{O}\right)$, carbon dioxide $\left(\mathrm{CO}_{2}\right)$, and methane $\left(\mathrm{CH}_{4}\right)$ from winter wheat cultivation expressed as $\mathrm{CO}_{2}$ equivalent emissions using the global warming potential (GWP) with values of 296 for $\mathrm{N}_{2} \mathrm{O}, 1$ for $\mathrm{CO}_{2}$, and 23 for $\mathrm{CH}_{4}$ [14]. Two metrics of GWP were determined: first, the quantity of GHG related to the production of a $\mathrm{kg}$ of grain, and second the quantity of GHG emitted per hectare of wheat. An assessment of GHG emissions in each farm was estimated by BioGrace calculation tool v. 4c [15].

\section{Results and Discussion}

\section{Inventory Data}

Table 1 presents a summary of inputs and outputs for three farm sizes of wheat production. Data refers to annual operation of each winter wheat farm. The average sizes of farms were 8.2, 15.2, and 29.3 ha for small, medium, and large farms, respectively (Table 1). The difference in farm sizes were statistically significant. There were not statistical difference in inputs (seeds, fertilizers, pesticides, diesel, and labour) between analysed farms. The small farms are characterised by lower input of nitrogen $(\mathrm{N})$ and phosphorus $\left(\mathrm{P}_{2} \mathrm{O}_{5}\right)$ fertilizers, and the highest input of diesel fuel compared to medium and large farms. Wheat yield of small farms was $5,309 \mathrm{~kg}$, medium was $5,508 \mathrm{~kg}$, and large was $6,718 \mathrm{~kg}$. The differences between wheat yields were statistically significant. Data availability was the essential requirement in our research. Therefore, data collection was a very important phase of the study because it determined the ability to perform analyses in accordance with the applied methodology.

\section{Current Environmental Characterization}

In this study, average GHG emissions were calculated per $\mathrm{kg}$ of winter wheat grain and per ha. The production of $1 \mathrm{~kg}$ winter wheat results with average emissions of 0.448 , 0.481 , and $0.411 \mathrm{~kg} \mathrm{CO}_{2}$ eq. per $\mathrm{kg}$ of grain for $\mathrm{A}, \mathrm{B}$, and $\mathrm{C}$ farms, respectively (Table 2).

Our results may be compared to the results from other countries. In the Czech Republic, GWP of wheat production was reported at 0.558 and $0.462 \mathrm{~kg} \mathrm{CO} \mathrm{C}_{2}$ eq. $\mathrm{kg}^{-1}$ for conventional and organic farming, respectively [16]. These differences are the consequences of different cultivation systems. In organic farming, farmers do not apply mineral fertilizers and pesticides, therefore GWP is lower than

Table 2. Greenhouse gas emissions of inputs per $\mathrm{kg}$ of wheat and per ha production based on farm size. Percentages share individual emissions in the total emissions.

\begin{tabular}{|c|c|c|c|c|c|c|c|c|c|}
\hline \multirow{3}{*}{ Item (unit) } & \multicolumn{6}{|c|}{ Farm size groups } & \multicolumn{3}{|c|}{ Farm size groups } \\
\hline & $\mathrm{A}$ & B & $\mathrm{C}$ & A & $\mathrm{B}$ & $\mathrm{C}$ & A & B & $\mathrm{C}$ \\
\hline & \multicolumn{3}{|c|}{ GHG (kg CO ${ }_{2}$ eq.) per kg } & \multicolumn{3}{|c|}{ GHG (kg CO ${ }_{2}$ eq.) per ha } & \multicolumn{3}{|c|}{ Percentage $(\%)$} \\
\hline Diesel & 0.058 & 0.052 & 0.044 & 309.2 & 286.5 & 298.5 & 13.00 & 10.82 & 10.82 \\
\hline Nitrogen $(\mathrm{N})$ & 0.140 & 0.160 & 0.132 & 741.8 & 883.9 & 887.4 & 31.19 & 33.38 & 32.17 \\
\hline Potassium $\left(\mathrm{K}_{2} \mathrm{O}\right)$ & 0.006 & 0.006 & 0.004 & 30.7 & 330.7 & 26.1 & 1.29 & 1.16 & 0.95 \\
\hline Phosphorus $\left(\mathrm{P}_{2} \mathrm{O}_{5}\right)$ & 0.009 & 0.009 & 0.007 & 45.9 & 48.7 & 47.1 & 1.93 & 1.84 & 1.71 \\
\hline Pesticides & 0.004 & 0.003 & 0.003 & 20.5 & 18.7 & 20.8 & 0.86 & 0.71 & 0.76 \\
\hline Seeding material & 0.010 & 0.008 & 0.008 & 54.8 & 41.4 & 51.9 & 2.30 & 1.56 & 1.88 \\
\hline Filed $\mathrm{N}_{2} \mathrm{O}$ emissions & 0.221 & 0.243 & 0.212 & $1,175.1$ & $1,337.9$ & $1,426.7$ & 49.42 & 50.53 & 51.72 \\
\hline Total GHG emissions & 0.448 & 0.481 & 0.411 & $2,378.0$ & $2,647.8$ & $2,758.5$ & 100.0 & 100.0 & 100.00 \\
\hline
\end{tabular}

A - small farms, B - medium farms, C - large farms 
Table 3. Technical efficiency (TE) and percentages of operational reduction for the small, medium, and large inefficient farms.

\begin{tabular}{|c|c|c|c|c|c|c|c|c|}
\hline \multirow{2}{*}{ DMU } & \multirow{2}{*}{$\mathrm{TE}$} & \multicolumn{7}{|c|}{ Operational reduction (\%) } \\
\hline & & Seeds & $\mathrm{N}$ fertilizer & $\mathrm{P}_{2} \mathrm{O}_{5}$ fertilizer & $\mathrm{K}_{2} \mathrm{O}$ fertilizer & Pesticides & Diesel & Labour \\
\hline $1 \mathrm{~A}$ & 0.76 & 42.46 & 24.09 & 74.65 & 96.10 & 26.54 & 24.09 & 24.09 \\
\hline $2 \mathrm{~A}$ & 0.59 & 40.93 & 40.93 & 58.62 & 42.38 & 51.63 & 40.93 & 40.93 \\
\hline $5 \mathrm{~A}$ & 0.64 & 45.64 & 35.98 & 68.51 & 89.45 & 50.02 & 35.98 & 35.98 \\
\hline $6 \mathrm{~A}$ & 0.39 & 60.89 & 60.89 & 80.00 & 91.02 & 60.89 & 61.84 & 65.11 \\
\hline $9 \mathrm{~A}$ & 0.79 & 29.50 & 20.79 & 20.79 & 50.87 & 23.53 & 20.79 & 20.79 \\
\hline $10 \mathrm{~A}$ & 0.89 & 10.81 & 10.81 & 10.81 & 75.53 & 10.81 & 17.62 & 30.97 \\
\hline $11 \mathrm{~A}$ & 0.71 & 30.52 & 28.68 & 57.68 & 64.27 & 29.85 & 28.68 & 28.68 \\
\hline $12 \mathrm{~A}$ & 0.80 & 34.00 & 22.31 & 84.77 & - & 19.85 & 24.27 & 44.76 \\
\hline $17 \mathrm{~A}$ & 0.94 & 5.90 & 5.90 & 5.90 & 48.99 & 31.91 & 5.90 & 15.20 \\
\hline Average $^{a}$ & 0.72 & 33.40 & 27.82 & 51.30 & 62.07 & 33.89 & 28.90 & 34.06 \\
\hline Average $^{\mathrm{b}}$ & 0.87 & 15.82 & 13.18 & 24.30 & 29.40 & 16.05 & 13.69 & 16.13 \\
\hline $4 \mathrm{~B}$ & 0.88 & 12.02 & 38.57 & 12.02 & 47.31 & 64.98 & 19.38 & 12.02 \\
\hline 9B & 0.49 & 50.66 & 50.66 & 50.66 & 76.71 & 76.33 & 65.26 & 60.60 \\
\hline $11 \mathrm{~B}$ & 0.87 & 20.18 & 13.37 & 13.37 & 39.00 & 23.98 & 20.71 & 13.37 \\
\hline $15 \mathrm{~B}$ & 0.94 & 6.25 & 36.53 & 45.96 & 68.32 & 6.25 & 43.41 & 6.25 \\
\hline $16 \mathrm{~B}$ & 0.98 & 2.02 & 2.02 & 2.02 & 33.36 & 51.36 & 2.72 & 2.02 \\
\hline 19B & 0.86 & 6.67 & 7.45 & 6.54 & 13.95 & 11.74 & 7.99 & 4.97 \\
\hline Average $^{c}$ & 0.84 & 16.30 & 24.77 & 21.76 & 46.44 & 39.11 & 26.58 & 16.54 \\
\hline Average $^{\mathrm{d}}$ & 0.95 & 6.67 & 7.45 & 6.54 & 13.95 & 11.74 & 7.99 & 4.97 \\
\hline $1 \mathrm{C}$ & 0.96 & 33.34 & 3.55 & 11.83 & 21.63 & 3.55 & 37.27 & 29.41 \\
\hline $3 \mathrm{C}$ & 0.95 & 14.01 & 45.23 & 5.18 & 36.78 & 5.18 & 15.09 & 20.28 \\
\hline $4 \mathrm{C}$ & 0.77 & 22.88 & 35.31 & 66.60 & 70.48 & 29.41 & 22.88 & 27.03 \\
\hline $5 \mathrm{C}$ & 0.79 & 44.88 & 32.95 & 35.29 & - & 29.13 & 21.29 & 21.45 \\
\hline $6 \mathrm{C}$ & 0.85 & 50.44 & 17.93 & 14.63 & - & 23.70 & 38.82 & 14.63 \\
\hline $9 \mathrm{C}$ & 0.89 & 12.30 & 27.15 & 10.71 & 10.71 & 35.13 & 33.80 & 10.71 \\
\hline $10 \mathrm{C}$ & 0.92 & 18.76 & 60.76 & 7.90 & 53.95 & 7.90 & 31.66 & 24.41 \\
\hline $14 \mathrm{C}$ & 0.83 & 30.74 & 28.63 & 16.77 & 16.77 & 73.09 & 30.30 & 16.77 \\
\hline $16 \mathrm{C}$ & 0.57 & 51.67 & 43.50 & 56.94 & 71.29 & 55.13 & 50.47 & 43.50 \\
\hline $17 \mathrm{C}$ & 0.88 & 39.04 & 37.62 & 11.98 & 0.50 & 11.98 & 33.86 & 30.02 \\
\hline Average $^{e}$ & 0.84 & 31.81 & 33.26 & 23.78 & 28.21 & 27.42 & 31.54 & 23.82 \\
\hline Average $^{f}$ & 0.91 & 18.71 & 19.57 & 13.99 & 16.59 & 16.13 & 18.56 & 14.01 \\
\hline
\end{tabular}

DMU - decision making unit

${ }^{a}$ Average of medium inefficient farms.

${ }^{\mathrm{b}}$ Average of farms of the whole medium sample.

${ }^{\mathrm{c}}$ Average of medium inefficient farms.

${ }^{\mathrm{d}}$ Average of farms of the whole medium sample.

${ }^{\mathrm{e}}$ Average of large inefficient farms.

${ }^{\mathrm{f}}$ Average of farms of the whole large sample. 
in conservation and conventional systems. The results from UK and Danish field trials show that the average GHG emissions when optimum $\mathrm{N}$ rate and disease control were applied amounted to $0.417 \mathrm{~kg} \mathrm{CO}$ eq. $/ \mathrm{kg}$, compared to $0.546 \mathrm{~kg} \mathrm{CO}$ eq. $\cdot \mathrm{kg}^{-1}$ when disease control was not applied [17]. The performed analysis shows that GHG emissions per hectare depend on farm size and ranged from 2,378 $\mathrm{kg} \mathrm{CO}_{2}$ eq. for small farms to $2,759 \mathrm{~kg} \mathrm{CO}$ eq. for large farms (Table 2). The average GHG emission of medium farms was 2,664 $\mathrm{kg} \mathrm{CO}$ eq. ha ${ }^{-1}$. Khoshnevisan et al. [18] reported total emissions of $2,711.58 \mathrm{~kg} \mathrm{CO}_{2} \mathrm{eq} \cdot \mathrm{ha}^{-1}$ for wheat production. In Berry et al. [17] studies, GHG emissions were very strongly influenced by the $\mathrm{N}$ fertilizer rate and disease control, and ranged from 1,498 to $4,176 \mathrm{~kg} \mathrm{CO}$ eq. $\mathrm{ha}^{-1}$. Therefore, it is very important to define optimum doses of agricultural inputs in order to limit unnecessary outlays and decrease emissions. The highest values of total GHG emissions belonged to $\mathrm{N}_{2} \mathrm{O}$ field emissions and $\mathrm{N}$ applications. The filed $\mathrm{N}_{2} \mathrm{O}$ emissions include emissions from the production of fertilizers. The sequence in all farm groups of other inputs to GWP was the following: diesel, seeds, phosphorus, potassium, and pesticides. The emissions varied depending on farm size (Table 2).

\section{DEA Performance}

The technical efficiency (TE) of inefficient DMU is presented in Table 3. From the 19 small farms, 10 (53\%) farms were recognized as efficient farms and the remaining $9(47 \%)$ were inefficient. The average TE of small inefficient farms was calculated as 0.72 . This indicates that the same yields could be produced with $72 \%$ of the inputs if these farms were operating efficiently. Another interpretation of these results is that $28 \%$ of overall resources could be saved by raising the performance of these DMUs to the highest level. Similar analyses were performed for medium and large farms. Based on our calculations, both in medium and large farms, $16 \%$ of inputs could be saved by improving efficiency of ineffective farms. In Estonian grain farms, the average TE varied from 0.70 to 0.78 [19]. Based on the literature, the technical efficiency scores of 0.89 for soybean farms [12], 0.80 and 0.71 for rice planted in spring and summer [20], and 0.78 for apple producers [21] were reported. Our results indicate that not all farmers are familiar with the correct technologies of winter wheat production or they did not apply them at a proper time in the optimum quantity. Furthermore, target operating points were estimated (operational benchmarking). These points that transform inefficient units into efficient ones are also presented in Table 3 as percentage reduction of the current operational values.

\section{Target Environmental Characterization}

After identifying inefficient farms and reduction levels of used inputs, a new environmental characterization was calculated for all inefficient farms. It was done in order to determine their potential environmental impacts if they
Table 4. GWP in target conditions for inefficient winter wheat farms per $\mathrm{kg}$ of wheat and per hectare and percentage reduction of GWP in target conditions.

\begin{tabular}{|c|c|c|c|}
\hline DMU & $\begin{array}{c}\text { GWP } \\
\left(\mathrm{kg} \mathrm{CO}_{2} \text { eq./kg) }\right.\end{array}$ & $\begin{array}{c}\text { GWP } \\
\left(\mathrm{kg} \mathrm{CO}_{2} \text { eq./ha) }\right.\end{array}$ & $\begin{array}{c}\text { Reduction } \\
(\%)\end{array}$ \\
\hline $1 \mathrm{~A}$ & 0.329 & 1,380 & 24.2 \\
\hline $2 \mathrm{~A}$ & 0.393 & 1,572 & 36.4 \\
\hline $5 \mathrm{~A}$ & 0.328 & 1,146 & 31.7 \\
\hline $6 \mathrm{~A}$ & 0.323 & 808 & 55.9 \\
\hline $9 \mathrm{~A}$ & 0.428 & 2,138 & 18.6 \\
\hline $10 \mathrm{~A}$ & 0.490 & 2,697 & 10.7 \\
\hline $11 \mathrm{~A}$ & 0.298 & 1,490 & 25.3 \\
\hline $12 \mathrm{~A}$ & 0.332 & 1,492 & 22.5 \\
\hline $17 \mathrm{~A}$ & 0.430 & 2,577 & 5.9 \\
\hline Average $^{a}$ & 0.372 & 1,700 & 25.7 \\
\hline $4 \mathrm{~B}$ & 0.512 & 2,611 & 33.5 \\
\hline $9 \mathrm{~B}$ & 0.504 & 1,182 & 38.8 \\
\hline $11 \mathrm{~B}$ & 0.399 & 1,772 & 10.5 \\
\hline $15 \mathrm{~B}$ & 0.449 & 1,795 & 27.1 \\
\hline $16 \mathrm{~B}$ & 0.451 & 2,928 & 3.0 \\
\hline 19B & 0.371 & 1,781 & 61.3 \\
\hline Average $^{b}$ & 0.448 & 2,011 & 29.0 \\
\hline $1 \mathrm{C}$ & 0.268 & 1,648 & 8.5 \\
\hline $3 \mathrm{C}$ & 0.293 & 2,051 & 33.9 \\
\hline $4 C$ & 0.378 & 2,371 & 31.0 \\
\hline $5 \mathrm{C}$ & 0.361 & 2,146 & 27.2 \\
\hline $6 \mathrm{C}$ & 0.341 & 1,705 & 19.0 \\
\hline $9 \mathrm{C}$ & 0.348 & 2,244 & 22.9 \\
\hline $10 \mathrm{C}$ & 0.288 & 1,881 & 49.2 \\
\hline $14 \mathrm{C}$ & 0.347 & 2,215 & 24.5 \\
\hline $16 \mathrm{C}$ & 0.290 & 1,415 & 38.9 \\
\hline $17 \mathrm{C}$ & 0.315 & 2,061 & 30.9 \\
\hline Average $^{c}$ & 0.323 & 1,974 & 28.6 \\
\hline
\end{tabular}

${ }^{a}$ Average of inefficient small farms.

${ }^{\mathrm{b}}$ Average of inefficient medium farms.

${ }^{\mathrm{c}}$ Average of inefficient large farms.

were managed under efficient operational conditions. The results in Table 4 show that if inefficient farms are run under optimal operational conditions, the reduction of GHG emissions is possible without any changes in the output level. In small farms, the reduction of GHG per $\mathrm{kg}$ of wheat varied from 0.298 to $0.490 \mathrm{~kg} \mathrm{CO}_{2}$ eq., with average values for the group of $0.372 \mathrm{~kg} \mathrm{CO}_{2}$ eq. In this group, the 
Table 5. Average percentage reduction in environmental impacts based on farm size.

\begin{tabular}{|c|c|c|c|}
\hline \multirow{3}{*}{ Item (unit) } & \multicolumn{3}{|c|}{ GWP reductions (\%) } \\
\hline & \multicolumn{3}{|c|}{ Farm size groups } \\
\hline & A & B & $\mathrm{C}$ \\
\hline Diesel & 14 & 11 & 19 \\
\hline Nitrogen $(\mathrm{N})$ & 11 & 9 & 23 \\
\hline Potassium $\left(\mathrm{K}_{2} \mathrm{O}\right)$ & 43 & 22 & 38 \\
\hline Phosphate $\left(\mathrm{P}_{2} \mathrm{O}_{5}\right)$ & 35 & 6 & 20 \\
\hline Pesticides & 18 & 23 & 22 \\
\hline Filed $\mathrm{N}_{2} \mathrm{O}$ emissions & 8 & 6 & 15 \\
\hline Total GHG emissions & 11 & 7 & 18 \\
\hline
\end{tabular}

$\mathrm{A}$ - small farms, B - medium farms, $\mathrm{C}$ - large farms

reduction in GHG emissions per hectare ranged from 808 to $2,697 \mathrm{~kg} \mathrm{CO}_{2}$ eq. with an average of $1,700 \mathrm{~kg} \mathrm{CO}_{2}$ eq. Percentage decrease of GWP inefficient small farms oscillated between 6 and $56 \%$, with average value of $25.7 \%$ due to a wide range in TE (39-94\%). In medium farms, the decrease of GHG emissions ranged from 0.371 to $0.512 \mathrm{~kg}$ $\mathrm{CO}_{2}$ eq. and from 1,182 to $2,928 \mathrm{~kg} \mathrm{CO}_{2}$ eq. per $\mathrm{kg}$ of wheat and per ha, respectively. Percentage reduction of GWP inefficient medium farms varied between 3 and $61 \%$, with an average of $29 \%$. In large farms, the average potential reduction of GHG is very similar (28.6\%) to medium farms, but higher than in small ones.

The results regarding the entire set of farms (Table 5) show an important potential environmental improvement of each operation and total GWP. In large farms the estimated potential of GWP reduction is $18 \%$, and $11 \%$ and $7 \%$ in small and medium farms, respectively. The potential reduction of GHG emission is linked with lower inputs. In large farms, operational reduction ranged from $19 \%$ (for diesel) to $38 \%$ (for potassium). Lower operational reduction was noticed for medium farms, e.g. from $6 \%$ (for phosphate) to $23 \%$ (for pesticides). The results obtained for input reduction in small farms varied from $11 \%$ (for $\mathrm{N}$ fertilizer) to $43 \%$ (for phosphate). In all farms, lower $\mathrm{N}$ fertilizer input had an impact on $\mathrm{N}_{2} \mathrm{O}$ field emission decreases. Our research shows that by increasing their operational efficiency, farms could have an impact on potential environmental improvement. This could be done by implementation of new production techniques that are more efficient.

In summary, the application of a combination of DEA and Biograce $4 \mathrm{c}$ tool shows the usefulness of benchmarking operational inputs and global warming impact in winter wheat cultivation in south-central Poland. The results of this study present the potential for GWP reduction in the surveyed farms. The performed analysis confirmed that the main contributor to GHG emissions in winter wheat cultivation is $\mathrm{N}_{2} \mathrm{O}$ field emissions and the application of $\mathrm{N}$ fertilizer. These emissions could be reduced by the application of optimal $\mathrm{N}$ fertilizer dose.

\section{Conclusions}

The present study was aimed at analysing the operational and environmental performance of winter wheat production in Poland's Wielkopolska and Silesian regions. A sample of 55 farms classified into three categories as small, medium, and large was analysed using the defined DEA methodology and Biograce $4 \mathrm{c}$ tool. From all farms considered for analysis, 25 were found to be inefficient. The share of inefficient farms was 47,32 , and $58 \%$ for small, medium, and large farms, respectively. The technical efficiency scores of inefficient farms were 0.72 for small farms and 0.84 for medium and large ones. The analysis shows that inefficient farms may save their resources by 28 (small farms) and 16\% (medium and large), adopting the best practices of high-performing benchmarks. These results indicate that not all farmers are familiarized with the correct technologies of winter wheat production or they did not apply them at a proper time in the optimum quantity. The projection computed for the inefficient farms after improving their efficiency resulted in lower environmental impact. Environmental reductions of the GWP of inefficient farms were calculated as $25.7,29.0$, and $28.6 \%$ for small, medium, and large farms, respectively. The estimated potential reduction of GHG emissions according to DEA for the whole sample of farms ranged from 7 to $18 \%$, and was dependent on farm size. The results of GHG analysis indicate that in total greenhouse emissions the highest share was field $\mathrm{N}_{2} \mathrm{O}$ emissions (49-52\%), followed by nitrogen fertilizer (31-33\%) and diesel fuel (11-13\%). The application of DEA and the Biograce $4 \mathrm{c}$ tool has proven to be a suitable method for quantifying operational and environmental performance. This technique could be used as a management tool to support decision-making processes.

\section{Acknowledgements}

The studies have been supported by The National Centre for Research and Development within the project Support for low carbon agriculture - able to adopt to observed climate change in the perspective of 2030 and 2050 (Acronym LCAgri).

\section{References}

1. FAO. FAO Statistical Yearbook - World food and agriculture. Food and Agriculture Organization of the United Nations, Rome. 2013.

2. CSO. Statistical yearbook of agriculture. Central Statistical Office, Warsaw. 2013.

3. SYP A., FABER A., BORZECCKA WALKER M. Simulation of soil organic carbon in long-term experiments in Poland using the DNDC model. J. Food Agric. Environ. 10, (3-4), 1224, 2012.

4. FAO. Food and nutrition in numbers. FAO, Rome. 2014.

5. HUERTA J.H., ALVEAR E.M., NAVARRO R.M. Evaluation of two production methods of Chilean wheat by life cycle assessment (LCA). IDESIA. 30, 101, 2012. 
6. CHARNES A., COOPER W.W., RHODES E. Measuring the efficiency of decision making units. Eur. J. Oper. Res. 2, 429, 1978

7. COOPER W.W., SEIFORD L.M., KAORU T. Introduction to Data Envelopment Analysis and Its Uses. New York. 2006.

8. KOEIJER T.J., WOSSINK G.A.A., STRUIK P.C., RENKEMA J.A. Measuring agricultural sustainability in term of efficiency: the case of Dutch suger beet growers. J. Environ. Manage. 66, 9, 2002.

9. MALANA M.N., MALANO M.H. Benchmarking productive efficiency of selected wheat areas in Pakistan and India using data envelopment ananlysis. Irrigation and Drainage, 55, 383, 2006.

10. BOLANDNAZAR E., KEYHANI A., OMID M. Determination of efficient and inefficient greenhouse cucumber producers using Data Envelopment Analysis approach, a case study: Jiroft city in Iran. J. Clean Prod. 79, 108, 2014.

11. KANELLOPOULOS A., REIDSMA P., WOLF J., VAN ITTERSUM M.K. Assessing climate change and associated socio-economic scenarios for arable farming in the Netherlands: An application of benchmarking and bio-economic farm modelling. Eur. J. Agron. 52, 69, 2014.

12. MOHAMMADI A., RAFIEE S., JAFARI A., DALGAARD T., KNUDSEN M.T., KEYHANI A., MOUSAVI-AVVAL S.H., HERMANSEN J.E. Potential greenhouse gas emission reductions in soybean farming: a combined use of Life Cycle Assessment and Data Envelopment Analysis. J. Clean Prod. 54, 89, 2013.

13. BANAEIAN N., OMID M., AHMADI H. Improvment of cost efficiency in strawberry greenhouse by data envelopment analysis. Agicultura Tropica et Subtropica, 44, 144, 2011.

14. FORSTER P., RAMASWAMY V., ARTAXO P., BERNTSEN T., BETTS R., FAHEY D.W., HAYWOOD J., LEAN J., LOWE D.C., MYHRE G., NGANGA J., PRINN R., RAGA G., SCHULZ M., VAN DORLAND R. Changes in Atmospheric Constituents and in Radiative Forcing. In: Climate Change 2007: The Physical Science Basis. Contribution of Working Group I to the Fourth Assessment Report of the Intergovernmental Panel on Climate Change [S. Solomon, D. Qin, M. Manning, Z. Chen, M. Marquis, K.B. Averyt, M. Tignor and H.L. Miller (Eds.)]. Cambridge University Press, Cambridge, United Kingdom and New York, NY, USA. 2007.

15. BIOGRACE. BioGrace calculation rules - version 4c. http://biograce.net/home, 2012

16. MOUDRÝ JR. J., JELÍNKOVÁ Z., PLCH R., MOUDRÝ J., KONVALINA P., HYŠPLER R. The emissions of greenhouse gases produced during growing and processing of wheat products in the Czech Republic. J Food Agric Environ. 11, (1), 1133, 2013.

17. BERRY P.M., KINDRED D.R., OLESEN J.E., JORGENSEN L.N., PAVELEY N.D. Quantifying the effect of interactions between disease control, nitrogen supply and land use change on the greenhouse gas emissions associated with wheat production. Plant Pathol. 59, 753, 2010.

18. KHOSHNEVISAN B., RAFIEE S., OMID M., YOUSEFI M., MOVAHEDI M. Modeling of energy consumption and GHG (greenhouse gas) emissions in wheat production in Esfahan province of Iran using artificial neural networks. Energy, 52, 333, 2013.

19. VASILIEV N., ASTOVER A., MÕTTE M., NOORMETS M., REINTAM E., ROOSTALU H. Efficiency of Estonian grain farms in 2000-2004. Agr. Food Sci. 17, 31, 2008.

20. MOHAMMADI A., RAFIEE S., JAFARI A., KEYHANI A, DALGAARD T., KNUDSEN M.T., NGUYEN T.L.T., BOREK R., HERMANSEN J.E. Joint Life Cycle Assessment and Data Envelopment Analysis for the benchmarking of environmental impacts in rice paddy production. J Clean Prod. 2014. http://dx.doi.org/10.1016/j.jclepro.2014.05.008

21. MOUSAVI-AVVAL S.H., RAFIEE S., MOHAMMAD A. Optimization of energy consumption and input costs for apple production in Iran using data envelopment analysis. Energy. 36, 909, 2011. 
